\section{THE EFFECT OF EXTERNAL STIMULI UPON THE CELL}

THE structure of the trophoplasm is an expression of the physiologic state. This structure consequently varies with the changing functional phases of the trophoplasm. Thus, in the root tip of Vicia faba the trophoplasm in the later stages of inanition becomes homogeneous; under the influence of antipyrine it becomes beautifully alveolar; under the influence of caffein it becomes granular; and in cells subjected to high pressure it becomes filar. The quantity of the trophoplasm is reduced as the cell activities are increased above the normal. Thus, in cells exposed to temperatures of 38 degrees Centigrade the trophoplasm is greatly reduced in quantity, and may appear not unlike the trophoplasm in advanced stages of inanition. A similar reduction is noticeable when cells are subjected to two-per-cent. solutions of antipyrine. On the other hand, cells subjected to low temperatures-zero degrees Centigrade to +2 -the cell activity is reduced and the trophoplasm increased in quantity. The same is true, though to a less extent, when cells are subjected to a two-per-cent. solution of chloral hydrate.

The kinoplasm is physiologically and morphologically distinct from the trophoplasm. It is destroyed at temperatures near zero degrees Centigrade and at 38 to 40 degrees. The trophoplasm endures these temperatures for a considerably longer time, with little or no injury. Chemical agents, like chloral hydrate, readily destroy the kinoplasm with little or no injury to the trophoplasm. The nucleolus varies in size, being large when the cell activity is greatly reduced and small when the cell activity is greatly increased. It is to be looked upon as reserve food material for general cellular activity. It is not food material solely for kinoplasm, nor does its substance penetrate the trophoplasm and thus activate or produce the kinoplasm.

It is difficult or impossible to explain the behavior of the mitotic spindle under the different stimuli, physical and chemical, with many of the theories now held in regard to spindle mechanism as a function.

C. F. Hottes

\section{THE AMERICAN ASSOCIATION FOR THE $A D V A N C E M E N T$ OF SCIENCE SECTION G-BOTANY}

THE session of Section G, Botany, was held at Cleveland on the afternoon of Tuesday, December 31,1912 . The program consisted of the address of the retiring vice-president, Professor F. C. Newcombe, on the topic "The Scope of State Natural History Surveys," and of the following invitation addresses: "The Effect of External Stimuli upon the Cell," Professor C. F. Hottes; "A Plea for Closer Interrelations in our Work," Professor L. R. Jones; "A Field Study of Oriental Cycads," Professor C. J. Chamberlain. Professor Newcombe's address has appeared in ScIENCE, and the invitation addresses will also be published in ScIence.

Professor Henry C. Cowles was elected vicepresident of Section $G$ for the foll ring year, and Professor W. J. V. Osterhout wis elected secretary for five years. Professor F. C. Newcombe was elected a member of the sectional committee for five years. Professor C. E. Allen and Professor B. E. Livingston were chosen as a special committee to consider affiliation with the Botanical Society of America. Henry C. Cowles, Secretary

\section{BOTANISTS OF THE CENTRAL STATES}

A SPECIAL business meeting of this organization was held in connection with the meetings of the American Association for the Advancement of Science at Cleveland, Tuesday, December 31, 1912. In the absence of the president, Professor T. H. Macbride, Past-president Professor F. C. Newcombe occupied the chair. The business of the meeting was to consider the desirability of again holding scientific sessions. The secretary read the results of a questionnaire that had been sent to the members, and in view of the large majority favoring active continuance, it was voted to hold meetings in the future in those years when the American Association for the Advancement of Science meets outside the territory of the Botanists of the Central States, which, broadly speaking, is the Mississippi Valley. Of those expressing an opinion, a majority favored holding meetings in conjunction with the zoologists, preferably about Easter.

Henry C. Cowles,

Secretary 


\section{Science}

\section{BOTANISTS OF THE CENTRAL STATES}

Henry C. Cowles

Science 38 (966), 32.

DOI: 10.1126/science.38.966.32-b

ARTICLE TOOLS

PERMISSIONS http://science.sciencemag.org/content/38/966/32.3.citation

http://www.sciencemag.org/help/reprints-and-permissions

Science (print ISSN 0036-8075; online ISSN 1095-9203) is published by the American Association for the Advancement of Science, 1200 New York Avenue NW, Washington, DC 20005. 2017 (C) The Authors, some rights reserved; exclusive licensee American Association for the Advancement of Science. No claim to original U.S. Government Works. The title Science is a registered trademark of AAAS. 